\title{
Chemical Analysis and Mechanical Properties of Selected Safety Components of Lifts
}

Petra Kvasnová1, Daniel Novák ${ }^{1}$, Viktor Novák ${ }^{2}$

${ }^{1}$ Matej Bel University, Faculty of Natural Sciences, Department of Technology, Tajovského 40, 97401 Banská Bystrica, Slovakia. E-mail: petra.kvasnova@umb.sk, daniel.novak@umb.sk

${ }^{2}$ Czech University of Life Sciences Prague, Faculty of Engineering, Department of Electrical Engineering and Automation, Kamýcká 129, 16521 Prague 6, Czech Republic. E-mail: novakviktor@tf.czu.cz

This paper deals with materials of selected safety components of lifts and it describes their mechanical and chemical testing. It particularly concerns with chemical analysis of two basic types of pulleys from gray and ductile cast iron, and subsequently with the measurement of the hardness and the strength of these materials. The aim of the research was to prove if these types of pulleys, widely used as safety components in the lift industry, meet the current law requirements. Finally, the results of the research are briefly discussed as well as their application in the university education.

Keywords: Lifts, Pulleys, Cast iron, Chemical analysis, Mechanical testing

\section{References}

[1] MELATRIM, S.R.O. (2014). Company documentation, Oravská Jasenica, Slovakia.

[2] HOCKICKO, P., KRIŠŤÁK, L., NĚMEC, M. (2015). Development of students' conceptual thinking by means of video analysis and interactive simulations at technical universities. In: European Journal of Engineering Education, Vol. 40, No. 2, pp. 145-166. ISSN 0304-3797.

[3] JOHN, B.S. (2015). HiST project. Connecting technology and people. Sør-Trøndelag University College, Faculty of Technology - 7004 Trondheim, Norway. [online], [cit. 2015-11-20]. <http://histproject.no/sites/histproject.no/files/2_20.pdf>.

[4] KUČERKA, M. (2013). Vybrané kapitoly zo strojov a zariadení. Belianum, Banská Bystrica, Slovakia. ISBN 978-80-557-0620-7.

[5] KURACINA, R., SZABOVÁ, Z., BALOG, K. (2015). Metódy analýzy rizík pri zváraní laserom. Kníhviazačstvo - Ing. Miroslav Binovec, Trnava, Slovakia. ISBN 978-80-972163-0-6.

[6] KVASNOVÁ, P. (2013). Materiály a technológie 3. Belianum, Banská Bystrica, Slovakia. ISBN 978-80-5570620-7.

[7] MRAČKOVÁ, E., KRIŠŤÁK, L., KUČERKA, M., GAFF, M., GAJTANSKA, M. (2016). Creation of wood dust during wood processing: Size analysis, dust separation, and occupational health. In: BioRes. 11(1), pp. 209222. ISSN 1930-2126.

[8] STEBILA, J. (2015). Inovatívne vyučovacie metódy a ich využitie v technickom vzdelávaní. Belianum, Banská Bystrica, Slovakia. ISBN 978-80-557-0944-4.

[9] STEBILA, J. (2010). New forms of natural sciences education in the context of lower secondary education in the Slovak Republic. In: Komunikacie, Vol. 12, No. 3, pp. 48-55. ISSN 1335-4205.

[10]VIRTUÁLNY INŠTITÚT MATNET (2015). Sivé liatiny, Ústav materiálov a mechaniky strojov SAV, Bratislava, Slovakia. [online], [cit. 2015-11-20]. 〈http://www.matnet.sav.sk/index.php?ID=146>.

[11]ZELENÝ, J., OČKAJOVÁ, A. (2013). Identifikácia a posudzovanie rizika. Belianum, Banská Bystrica, Slovakia. ISBN 978-80-557-0586-6.

[12]ŽÁČOK, L. (2014). Trendy technického a odborného vzdelávania v súčasnej škole. Belianum, Banská Bystrica, Slovakia. ISBN 978-80-557-0775-4. 